\title{
PENGEMBANGAN SISTEM PENCARI PAKAR DENGAN MENGGUNAKAN METODE ASSOCIATION RULES
}

\author{
Moehammad Arief Furqon dan Dana Indra Sensuse \\ Fakultas Ilmu Komputer, Universitas Indonesia, Kampus Baru UI Depok, 16424 \\ Email: dana@cs.ui.ac.id
}

\begin{abstract}
Abstrak
Suatu organisasi membutuhkan informasi tentang kondisi kepakaran. Salah satu aspek yang dapat digunakan dalam menentukan kepakaran di institusi pendidikan tinggi adalah publikasi ilmiah yang pernah dibuat. Penelitian ini bertujuan untuk mendapatkan informasi tentang kepakaran berdasarkan publikasi yang pernah dibuat. Penelitian ini menggunakan metode association rules untuk mendapatkan informasi tentang kepakaran berdasarkan publikasi yang ada. Di sini, dilihat tingkat kemunculan nama seseorang pada koleksi publikasi pada bidang yang sejenis. Hasil penelitian ini sebuah model pencarian informasi yang bermanfaat bagi manajemen puncak untuk mengetahui kepakaran seseorang. Dengan demikian, pengambilan keputusan oleh manajemen puncak dapat terlaksana dengan bantuan pakar yang tepat.
\end{abstract}

Kata kunci: Sistem Pencari Pakar, association rules, manajemen pengetahuan

\begin{abstract}
An organization needs information about the condition of expertise. One aspect that can be used in determining expertise in higher education institutions is a scientific publication ever made. This study aimed to obtain information about the expertise by publications ever created. This study uses association rules to obtain information about existing expertise based publications. Here, seen the emergence rate of a person's name on a collection of similar publications in the field. Results of this study a model of information retrieval for the benefit of top management expertise to know someone Thus, decision-making by top management can be accomplished with the help of appropriate experts.
\end{abstract}

Keywords: Expert system, association rules, knowledge management

\section{Pendahuluan}

Sebagai institusi pendidikan, perguruan tinggi memberikan pendidikan berbagai kompetensi kepada para peserta didiknya. Berbagai kompetensi tersebut diajarkan oleh dosen dengan berbagai latar belakang kompetensi. Tingkat kepakaran dosen pada suatu bidang kompetensi yang sama dapat berbeda-beda.

Mahasiswa serta manajemen perguruan tinggi adalah elemen utama dalam sebuah institusi pendidikan. Kedua elemen itu memiliki kebutuhan untuk mengetahui pakar suatu bidang di perguruan tinggi tersebut. Bagi mahasiswa, pengetahuan tentang orang yang menjadi pakar pada suatu bidang di perguruan tinggi tersebut berguna untuk membantu proses pendidikan yang mereka jalankan. Bagi pihak manajemen perguruan tinggi, hal ini dapat digunakan untuk memberikan gambaran mengenai kondisi kepakaran di perguruan tinggi tersebut. Hal tersebut dapat dijadikan dasar untuk pengambilan keputusan oleh pihak manajemen. Keputusan tersebut dapat berupa perekomendasian pakar tersebut kepada pihak-pihak yang membutuhkan maupun berupa penugasan.

Penemuan pakar tersebut harus bersifat objektif berdasarkan parameter-parameter yang telah ditentukan. Parameter-parameter tersebut dapat berupa publikasi ilmiah yang pernah dikeluarkan oleh dosen yang bersangkutan, riwayat pendidikan, riwayat riset serta proyek, riwayat mengajar, dan lain-lain. Tingkat kepakaran dapat dilihat dari semakin banyaknya parameter-parameter yang dimiliki.

Proses untuk mendapatkan pengetahuan dari individu, organisasi, maupun dokumen disebut knowledge capturing. Individu yang menjadi sumber pengetahuan sebaiknya adalah orang yang pakar di bidang tersebut. Dengan demikian, pengetahuan yang didapatkan menjadi akurat dan proses yang terjadi efektif. Proses ini merupakan bagian dari knowledge management solution.

Berdasarkan uraian tersebut, sistem untuk mendapatkan informasi tentang dosen yang pakar di suatu bidang menjadi penting. Hal ini disebabkan oleh perlunya mendapatkan informasi yang tepat mengenai pakar di suatu bidang. 
Dengan mengetahui pakar di suatu bidang, permasalahan yang terjadi pada suatu bidang dapat dikonsultasikan solusinya pada pakar yang tepat. Sebagai contoh, pemerintah memiliki masalah dengan infrastuktur teknologi informasi untuk menunjang proses penanggulangan bencana. Untuk itu, pemerintah meminta masukan dari pakar teknologi informasi dari kalangan akademisi. Tentu saja pemerintah meminta agar tiap perguruan tinggi dapat memberikan nama pakar terbaik di bidang teknologi informasi. Apabila dalam pemberian rekomendasi nama dari perguruan tinggi tersebut kepada pemerintah terjadi kesalahan akibat dari kegagalan sistem dalam mencari pakar, masukan yang didapatkan oleh pemerintah tidak optimal untuk menyelesaikan masalah yang dihadapi.

Teknologi data mining dapat digunakan untuk mendapatkan pakar berdasarkan parameterparameter yang telah ditetapkan. Data mining adalah proses untuk mendapatkan informasi baru berdasarkan pola dari data yang telah tersedia [1]. Ada berbagai teknik pada data mining untuk mendapatkan pengetahuan dari data yang tersedia. Teknik-teknik tersebut antara lain sebagai berikut.

1. Association rules. Teknik data mining dengan cara melihat korelasi pada suatu variabel dengan variabel lain.

2. Klasifikasi hierarki. Teknik data mining dengan cara membagi data yang dimiliki menjadi beberapa bagian yang berhierarki.

3. Pola sekuensial. Teknik data mining dengan cara melihat data yang sekuensial.

4. Pola pada waktu yang sama. Teknik data mining dengan cara melihat kemiripan data pada rentang waktu yang sama.

5. Klaster. Teknik data mining dengan cara membagi data berdasarkan kemiripan yang dimiliki.

Berdasarkan uraian tersebut, penulis memilih metode yang diterapkan dalam penelitian ini adalah association rules. Hal tersebut karena dengan menggunakan metode association rules, kita dapat mengetahui korelasi antar variabel yang digunakan dalam penelitian ini, yaitu dosen dan bidang kompetensi dari publikasi ilmiah yang ditulis.

\section{Manajemen Pengetahuan (Knowledge management/KM)}

Untuk membahas tentang KM, penulis terlebih dahulu membahas data, informasi, pengetahuan/knowledge, dan manajemen. Fernandez, Gonzales, dan Sabherwal [2] mendefinisikan data, informasi, dan pengetahuan sebagai berikut. Data terdiri atas fakta, hasil pengamatan, atau persepsi. Nilai kebenaran dari suatu data masih mungkin bernilai benar atau salah. Contoh dari data adalah daftar harga barang-barang kebutuhan pokok dari toko A dan B.

Informasi merupakan bagian dari data. Data yang dapat menjadi informasi harus memiliki konteks, relevansi, dan tujuan. Suatu data dapat menjadi informasi atau tidak. Hal tersebut dapat bergantung pada orang yang menggunakan. Contoh data yang penulis berikan sebelumnya juga merupakan informasi bagi konsumen. Dengan informasi tersebut, konsumen dapat menentukan pilihan tempat membeli kebutuhan pokok yang dibutuhkan.

Pengetahuan dapat didefinisikan sebagai informasi yang memiliki arah serta digunakan untuk mengambil keputusan. Dengan demikian, dapat dikatakan bahwa knowledge berada pada level tertinggi, informasi pada level tengah, dan data pada level tertinggi dari hirarki. Contoh pengetahuan adalah informasi mengenai penjualan, persediaan barang di gudang, serta pembelian bahan baku suatu produk pada sebuah perusahaan. Dengan informasi tersebut, perusahaan dapat memutuskan kuantitas serta waktu yang tepat untuk membeli bahan baku.

Pengetahuan yang diekspresikan dalam bentuk tertulis disebut sebagai explicit knowledge. Sedangkan pengetahuan yang tidak terekspresikan dalam bentuk tertulis disebut tacit knowledge. Contoh explicit knowledge adalah analisis pasar saham dalam sebuah buku. Contoh tacit knowledge adalah intuisi dan firasat.

Manajemen adalah suatu proses perencanaan, pengorganisasian, pelaksanaan dan pengendalian atas pemanfaatan sumber daya perusahaan dalam rangka mencapai tujuan perusahaan. Selain itu, manajemen juga dapat diartikan sebagai proses mengoordinasikan dan mengawasi pekerjaan lain hingga pekerjaan tersebut dapat diselesaikan dengan efisien dan efektif [3].

Menurut Stoner manajemen adalah suatu proses perencanaan, pengorganisasian, kepemimpinan, dan pengendalian upaya dari anggota organisasi serta penggunaan semua sumber daya yang ada pada organisasi untuk mencapai tujuan organisasi yang telah ditetapkan sebelumnya [4].

Secara singkat, Hendrik menyimpulkan manajemen pengetahuan sebagai proses merencanakan, mengumpulkan, mengorganisasi, serta mengendalikan data dan informasi yang telah digabung dengan berbagai bentuk pemikiran dan analisis dari berbagai sumber yang dianggap memiliki kompetensi [5].

Penerapan manajemen pengetahuan dalam sebuah organisasi berdampak positif bagi 
individu, proses, produk yang dihasilkan, serta kinerja organisasi [2]. Bagi individu pada organisasi tersebut, penerapan manajemen pengetahuan memfasilitasi individu tersebut untuk belajar, beradaptasi, dan memberikan kepuasan kerja. Dampak positif penerapan manajemen pengetahuan pada proses di organisasi tersebut dapat dilihat dengan tingkat keefektifan, keefisienan, dan inovasi. Dampak penerapan manajemen pengetahuan pada produk yang dihasilkan dapat dilihat dari nilai tambah yang ada pada produk tersebut serta pengetahuan dasar (knowledge-based) yang terkandung. Bagi kinerja organisasi, penerapan manajemen pengetahuan memiliki dampak langsung serta tidak langsung. Dampak langsung yang didapatkan adalah meningkatnya inovasi produk yang mengakibatkan pendapatan serta laba perusahaan. Dampak tidak langsung yang diperoleh adalah meningkatnya loyalitas konsumen serta mendapatkan posisi negosiasi yang menguntungkan pada mitra maupun pesaing.

Knowledge management membuat berbagi informasi menjadi bermantaat. Knowledge management termasuk strategi dari tanggung jawab dan tindak lanjut (commitment), baik untuk meningkatkan efektifitas organisasi maupun untuk meningkatkan peluang [6]. Tujuan dari knowledge management adalah meningkatkan kemampuan organisasi untuk melaksanakan proses inti lebih efisien.

\section{Pakar}

Menurut Kamus Besar Bahasa Indonesia dalam Jaringan pakar adalah orang yang memiliki keahlian di bidang ilmu tertentu, seperti biologi, fisika, dan kimia [7]. Definisi lain dari pakar ini juga disampaikan pada Ensiklopedia Reference.com [8]. Seorang pakar didefinisikan sebagai seseorang yang secara luas diakui sebagai sumber yang dapat dipercaya dalam hal teknis atau keterampilan untuk menilai atau memutuskan dengan tepat, adil, dan bijak. Pengakuan tersebut diberikan oleh orang-orang di sekitar atau masyarakat umum. Secara umum, seorang pakar adalah orang yang memiliki pengetahuan luas atau kemampuan pada bidang tertentu.

Menurut Rahmat pakar adalah orang yang memiliki pengetahuan, penilaian, metode khusus, serta kemampuan untuk menerapkan bakat ini dalam memberikan nasihat dan memecahkan masalah [9]. Pakar biasanya memiliki beberapa konsep umum. Pakar harus mampu memecahkan persoalan dan mencapai tingkat performa secara signifikan lebih baik dari orang kebanyakan.
Seseorang dapat dikatakan menjadi pakar di suatu bidang jika setidaknya telah memenuhi kriteria seperti berikut [10]:

- dapat mengenali dan merumuskan masalah,

- menyelesaikan masalah dengan cepat dan tepat,

- menjelaskan solusi,

- mampu belajar dari pengalaman,

- merekonstruksi pengetahuan,

- menentukan relevansi/hubungan, dan

- memahami batas kemampuan.

Cole mengungkapkan bahwa riset adalah bagian dari upaya akademik untuk menemukan solusi ilmiah persoalan-persoalan manusia atau proses penciptaan pengetahuan baru [11]. Di dalam kegiatan riset tersebut, terkandung sekaligus tiga aspek kognitif dari ilmu pengetahuan, yakni fact of attention, tingkat perkembangan, dan isi intelektual. Ketiga hal tersebut dapat tercermin dalam bentuk berbagai penelitian yang memusatkan perhatian pada masalah tertentu.

\section{Data Mining}

Menurut Elmasri dan Navathe data mining dapat diartikan sebagai proses menggali atau mendapatkan informasi baru berdasarkan pola atau aturan dari data yang tersedia [1]. Data mining merupakan bagian dari proses knowledge discovery. Sedangkan menurut Pramudiono, data mining adalah serangkaian proses untuk menggali nilai tambah dari sekumpulan data berupa pengetahuan yang selama ini tidak diketahui secara manual [12].

Menurut Elmasri dan Navathe [1] tujuan data mining adalah sebagai berikut:

- Prediksi. Data mining dapat memprediksi perilaku kondisi suatu variabel pada data di masa yang akan datang.

- Identifikasi. Pola dari data dapat digunakan untuk mengidentifikasi sebuah kejadian atau aktivitas.

- Klasifikasi. Data mining dapat membagi data menjadi beberapa kelas atau kategori berbeda yang diidentifikasi berdasarkan kombinasi dari parameternya.

- Optimisasi. Data mining dapat mengoptimalkan penggunaan berbagai sumber daya yang terbatas, seperti uang, waktu, tempat, bahan, sehingga dapat menghasilkan luaran yang optimal.

Menurut Liu dan Wang [13], metode dalam data mining dapat digolongkan sebagai berikut.

- Karakterisasi 
- Diskriminasi

- Association rules

- Klasifikasi

- Prediksi

- Analisis outlier

- Analisis evolusi dan deviasi

- Visualisasi

Konsep data mining menjadi semakin populer sebagai alat bisnis informasi manajemen yang diharapkan dapat mengungkapkan struktur pengetahuan yang bisa menuntun keputusan yang mengarah pada kepastian 14].

\section{Association rules}

Salah satu teknik yang umum digunakan pada data mining dan basis data adalah association rules. Association rules adalah sekumpulan aturan dalam bentuk $\mathrm{X} \rightarrow \mathrm{Y}$ (dibaca jika $\mathrm{X}$ maka $\mathrm{Y}$ ). Association rules merupakan proses pemilihan satu aturan dari sekumpulan aturan yang ada dengan menggunakan nilai support dan confidence lebih dari atau sama dengan nilai support dan confidence yang ditentukan [1]. Tujuan dari metode association rules adalah untuk mendeteksi hubungan atau asosiasi antara nilai-nilai tertentu dari variabel-variabel pada basis data yang besar [14].

IBM [15] menyatakan bahwa nilai support pada association rules adalah persentase kelompok yang memiliki semua hal yang tercantum pada aturan asosiasi. Nilai persentasenya dihitung dari seluruh kelompok yang ada. Nilai ini merepresentasikan tingkat intensitas aturan asosiasi tersebut muncul pada seluruh aturan yang ada. Dengan kata lain, nilai support dapat dituliskan sebagai $\frac{x}{y} \times 100 \%$ dengan $x$ adalah banyaknya aturan dan $y$ adalah banyaknya seluruh aturan yang ada.

Nilai confidence pada association rules adalah persentase nilai yang menunjukkan frekuensi kemunculan aturan tersebut dibandingkan dengan kemunculan bagian sebelah kanan dari aturan. Dengan kata lain jika terdapat aturan $p \rightarrow q$, nilai confidence dari aturan tersebut dapat dituliskan sebagai sebagai $\frac{x}{y} \times 100 \%$ dengan $x$ adalah banyaknya aturan $p$ beserta $q$ secara bersamaan dan $y$ banyaknya kemunculan $q$. Nilai confidence memperlihatkan tingkat kepercayaan pada aturan tersebut. Semakin tinggi nilai confidence, semakin sering pula tingkat asosiasi kehadiran aturan tersebut [16].

\section{Previous Works}

\subsection{Expert seeker}

Fernandez [17] mengungkapkan bahwa Expert seeker adalah sebuah repositori pengetahuan yang mencoba untuk mengelola pengetahuan yang ada yang merujuk pada orang yang memiliki pengetahuan khusus di NASA. Tujuan dari dibuatnya Expert seeker ini adalah sebagai berikut:

- menganalisis jenis, sumber, dan penggunaan pengetahuan pada sebuah organisasi,

- mengembangkan seperangkat sistem dengan spesifikasi rinci dan rencana implementasi rinci kegiatan yang akan datang,

- membuat perancanaan dengan rinci untuk menghadapi kebutuhan di masa depan,

- mengumpulkan data untuk mengimplementasikan prototipe yang akan membahas beberapa kebutuhan manajemen pengetahuan di Kennedy Space Center, NASA.

Pengembangan Expert seeker memanfaatkan data yang telah ada sebelumnya. Data tersebut antara lain data sumber daya manusia (SDM), keterampilan. Data SDM meliputi latar belakang pendidikan serta nomor kontak pegawai. Data keterampilan meliputi area kompetensi, alat evaluasi kinerja serta prestasi pegawai yang disebut dengan Global Performance Evaluation System (GPES), dan Project Resource Management System (PRMS). Informasi lain yang dianggap penting yang tidak tersedia pada basis data internal, dapat ditambahkan oleh pengguna. Data tersebut misalnya foto pegawai, data partisipasi pada proyek, hobi, serta aktivitas pengabdian masyarakat. Gambar 1 berikut ini menggambarkan arsitektur dari Expert seeker.

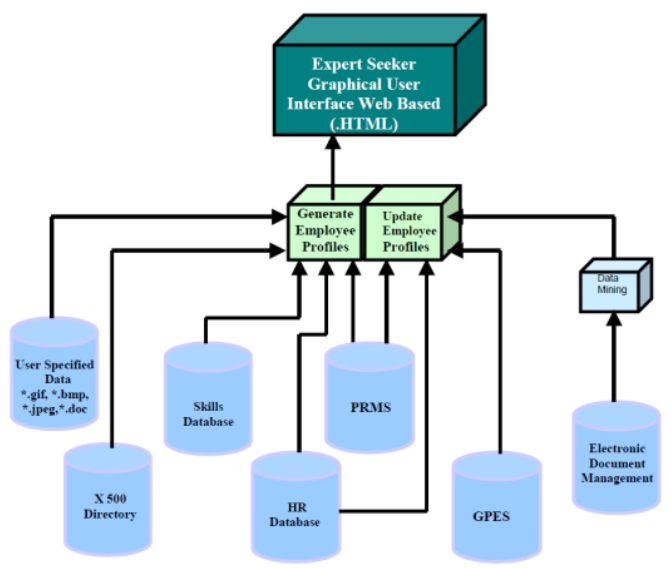

Gambar 1. Arsitektur expert seeker NASA [17] 


\subsection{Searchable Answer Generating \\ Environment (SAGE)}

SAGE adalah Knowledge management System yang digunakan untuk mencari pakar yang berada pada berbagai perguruan tinggi di Florida. SAGE muncul karena ada dua kebutuhan, yaitu kebutuhan untuk validasi data yang digunakan untuk mengidentifikasi pakar serta pada saat yang sama meminimalkan dampak pengumpulan data yang dibutuhkan [18].

Tampilan utama pada SAGE berupa formulir untuk memasukkan bidang keahlian yang akan dicari pakarnya. Masukan dari pengguna tersebut akan diproses menjadi query untuk pencarian data yang akan diproses. Sistem akan mengolah query tersebut sehingga menghasilkan jawaban berupa pakar dari bidang yang ditanyakan oleh pengguna.

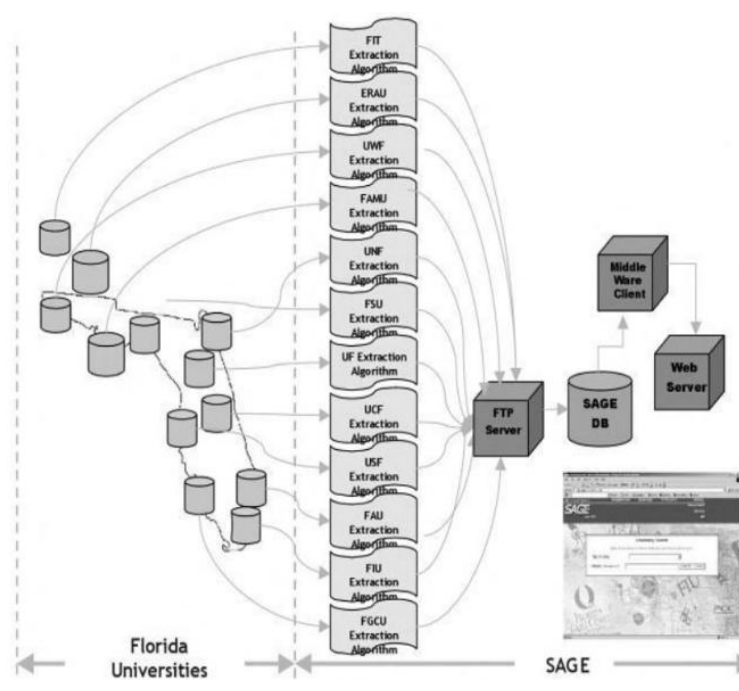

Gambar 2. Arsitektur searchable answer generating environment [17]

Gambar 2 menunjukkan arsitektur dari SAGE. Tampak pada gambar tersebut bahwa SAGE menggabungkan berbagai basis data yang tersebar di berbagai universitas di Florida. Keuntungan dari metode ini adalah pengguna dapat melakukan pencarian langsung ke berbagai basis data yang telah tergabung pada SAGE dengan langsung memasukkan query ke halaman utama aplikasi berbasis web ini.

\section{Metodologi Penelitian}

Berikut ini adalah metodologi penelitian yang penulis gunakan.

- Studi literatur

- Pengumpulan data

- Perancangan dan pengembangan sistem

- Uji coba

- Analisis hasil

\section{Arsitektur Sistem}

\subsection{Use Case Sistem}

Gambar 3 adalah use case diagram dari Sistem Pencari Pakar.

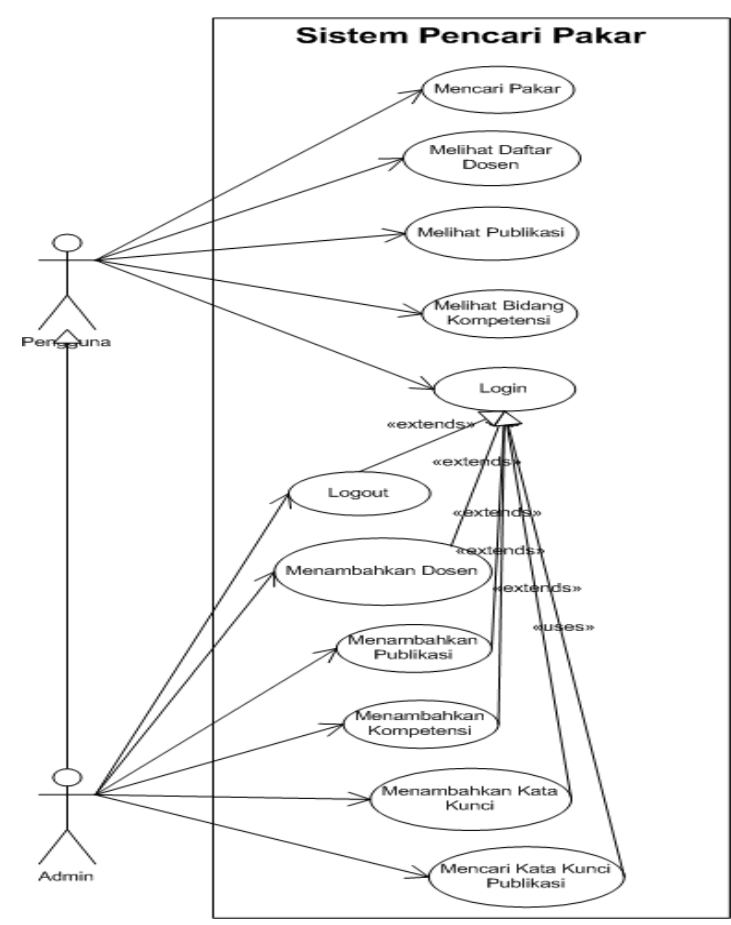

Gambar 3. Use case diagram sistem pencari pakar

Deskripsi tiap use case tersebut akan dijelaskan pada Tabel I.

\subsection{Basis Data}

Data yang dibutuhkan dalam menjalankan sistem ini dikumpulkan pada sebuah basis data. Data tersebut meliputi data dosen, publikasi, bidang kompetensi, kata kunci, serta user yang selanjutnya akan disebut sebagai entity. Hubungan antar-entity yang terjadi adalah dosen menulis publikasi, publikasi memiliki kata kunci, dan kompetensi memiliki kata kunci. Entity Relationship Diagram (ERD) dari Sistem Pencari Pakar ini dapat dilihat pada Gambar 4.

Entity dosen menyimpan atribut-atribut mengenai dosen Fasilkom UI. Atribut pada entity dosen ini adalah id dosen, nama, gelar S1, gelar S2, gelar S3, gelar profesi, serta keprofesoran. Entity publikasi menyimpan atribut dari publikasi ilmiah yang pernah dibuat oleh dosen Fasilkom UI. Entity publikasi ini berisi atribut id publikasi, judul, tempat, tahun, dan abstrak. Entity kata kunci merupakan kumpulan kata kunci yang mengasosiasikan bidang kompetensi yang ada. Entity ini berisi atribut id kata kunci, dan nama kata kunci. Entity kompetensi merupakan entity yang berisi tentang bidang keilmuan yang akan 
dicari orang yang ahli di bidang tersebut. Entity kompetensi ini berisi atribut id kompetensi dan nama kompetensi. Entity user berisi atribut username, password, serta status. Entity user ini berfungsi untuk menyimpan data pengguna yang berhak masuk ke sistem dan melakukan pengolahan data. Untuk saat ini, belum ada pembedaan tingkatan pengguna dalam melakukan pengolahan data sehingga atribut status masih belum berpengaruh.

Tiap entity yang ada diimplementasikan sebagai sebuah tabel dalam basis data MySQL. Gambar 5 adalah implementasi dari entity yang telah disebutkan.

TABEL I

DESKRIPSI USE CASE

\begin{tabular}{|c|c|c|c|}
\hline No. & $\begin{array}{l}\text { Nama } \\
\text { Use } \\
\text { Case }\end{array}$ & Aktor & Deskripsi \\
\hline 1. & $\begin{array}{l}\text { Mencari } \\
\text { pakar }\end{array}$ & Pengguna & $\begin{array}{l}\text { Use case ini digunakan oleh } \\
\text { pengguna untuk melakukan } \\
\text { pencarian pakar. }\end{array}$ \\
\hline 2. & $\begin{array}{l}\text { Melihat } \\
\text { daftar } \\
\text { dosen }\end{array}$ & Pengguna & $\begin{array}{l}\text { Use case ini digunakan oleh } \\
\text { pengguna untuk melihat } \\
\text { daftar dosen yang terdaftar } \\
\text { pada sistem. }\end{array}$ \\
\hline 3. & $\begin{array}{l}\text { Melihat } \\
\text { publikasi }\end{array}$ & Pengguna & $\begin{array}{l}\text { Use case ini digunakan oleh } \\
\text { pengguna untuk melihat } \\
\text { publikasi yang terdaftar pada } \\
\text { sistem. }\end{array}$ \\
\hline 4. & $\begin{array}{l}\text { Melihat } \\
\text { Bidang } \\
\text { Kompe- } \\
\text { tensi }\end{array}$ & Pengguna & $\begin{array}{l}\text { Use case ini digunakan oleh } \\
\text { pengguna untuk melihat } \\
\text { daftar bidang kompetensi } \\
\text { beserta kata kunci yang } \\
\text { bersesuaian. }\end{array}$ \\
\hline 5. & Login & Pengguna & $\begin{array}{l}\text { Use case ini digunakan oleh } \\
\text { pengguna untuk masuk ke } \\
\text { sistem sebagai admin. }\end{array}$ \\
\hline 6. & Logout & Admin & $\begin{array}{l}\text { Use case ini digunakan oleh } \\
\text { admin untuk keluar dari } \\
\text { sistem. }\end{array}$ \\
\hline 7. & $\begin{array}{l}\text { Menam- } \\
\text { bahkan } \\
\text { dosen }\end{array}$ & Admin & $\begin{array}{l}\text { Use case ini digunakan oleh } \\
\text { admin untuk menambahkan } \\
\text { dosen. }\end{array}$ \\
\hline 8. & $\begin{array}{l}\text { Menam- } \\
\text { bahkan } \\
\text { publikasi }\end{array}$ & Admin & $\begin{array}{l}\text { Use case ini digunakan oleh } \\
\text { admin untuk menambahkan } \\
\text { publikasi. }\end{array}$ \\
\hline 9. & $\begin{array}{l}\text { Menam- } \\
\text { bahkan } \\
\text { kompe- } \\
\text { tensi }\end{array}$ & Admin & $\begin{array}{l}\text { Use case ini digunakan oleh } \\
\text { admin untuk menambahkan } \\
\text { bidang kompetensi. }\end{array}$ \\
\hline 10. & $\begin{array}{l}\text { Menam- } \\
\text { bahkan } \\
\text { kata } \\
\text { kunci }\end{array}$ & Admin & $\begin{array}{l}\text { Use case ini digunakan oleh } \\
\text { admin untuk menambahkan } \\
\text { kata kunci pada bidang } \\
\text { kompetensi. }\end{array}$ \\
\hline 11. & $\begin{array}{l}\text { Mencari } \\
\text { kata } \\
\text { kunci } \\
\text { publikasi }\end{array}$ & Admin & $\begin{array}{l}\text { Use case ini digunakan oleh } \\
\text { admin untuk mencocokkan } \\
\text { kata kunci yang terdaftar } \\
\text { pada sistem dengan data } \\
\text { publikasi. }\end{array}$ \\
\hline
\end{tabular}

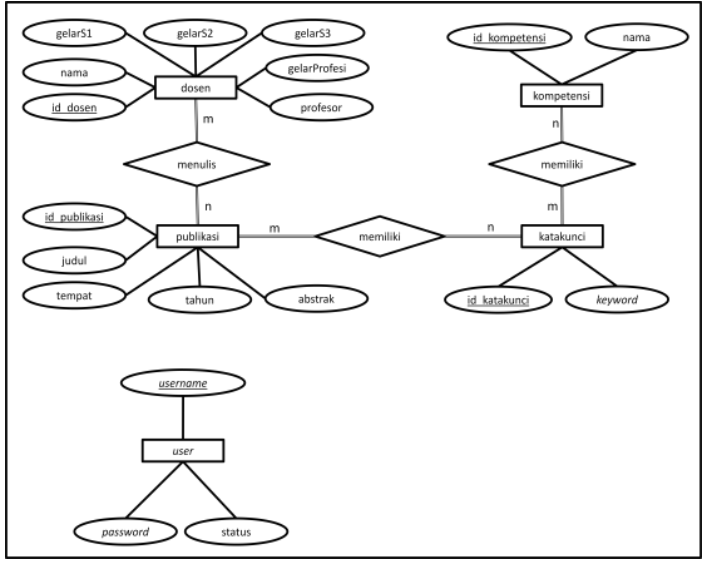

Gambar 4. Entity relationship diagram

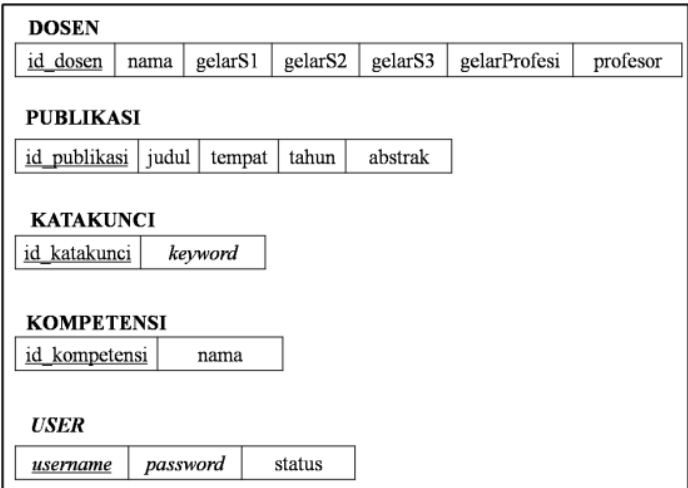

Gambar 5. Implementasi entity pada MySQL

Sebagaimana yang telah disebutkan sebelumnya, ada hubungan antar-entity pada basis data ini. Entity dosen berhubungan dengan entity publikasi. Hubungan tersebut adalah dosen menulis publikasi. Keterhubungan di sini bersifat many to many yang artinya tiap dosen dapat menulis banyak publikasi dan tiap publikasi dapat ditulis oleh banyak dosen. Pada basis data MySQL, hubungan ini diimplementasikan sebagai tabel penulis yang memiliki atribut id_dosen dan id_publikasi. Pada tabel ini, atribut id_dosen merujuk ke atribut id_dosen pada tabel dosen sedangkan atribut id_publikasi merujuk pada atribut id_publikasi pada tabel publikasi.

Entity publikasi berhubungan pula dengan entity kata kunci. Hubungan yang terjadi adalah tiap publikasi memiliki beberapa kata kunci. Tiap kata kunci pun dapat dimiliki oleh beberapa publikasi. Dengan demikian, hubungan ini bersifat many to many. Pada basis data MySQL, hubungan ini diimplementasikan sebagai tabel 
katakunci_publikasi yang memiliki atribut id_publikasi dan id_katakunci. Pada tabel ini, atribut id_publikasi merujuk pada atribut id_publikasi pada tabel publikasi sedangkan atribut id_katakunci merujuk ke atribut id_katakunci pada tabel katakunci.

Entity kata kunci juga berhubungan dengan entity kompetensi. Hubungan yang terjadi pada kedua entity ini adalah tiap kompetensi dapat memiliki banyak kata kunci dan tiap kata kunci dapat dimiliki oleh beberapa kompetensi. Dengan demikian, hubungan yang terjadi bersifat many to many. Pada basis data MySQL, hubungan ini diimplementasikan sebagai tabel katakunci_kompetensi yang beratribut id_kompetensi dan id_katakunci. Atribut id_kompetensi pada tabel ini merujuk pada atribut id_kompetensi pada tabel kompetensi sedangkan id_katakunci pada tabel ini merujuk pada atribut id_katakunci pada tabel katakunci.

Hasil pemetaan (mapping) basis data Sistem Pencari Pakar ini dapat dilihat pada Gambar 6.

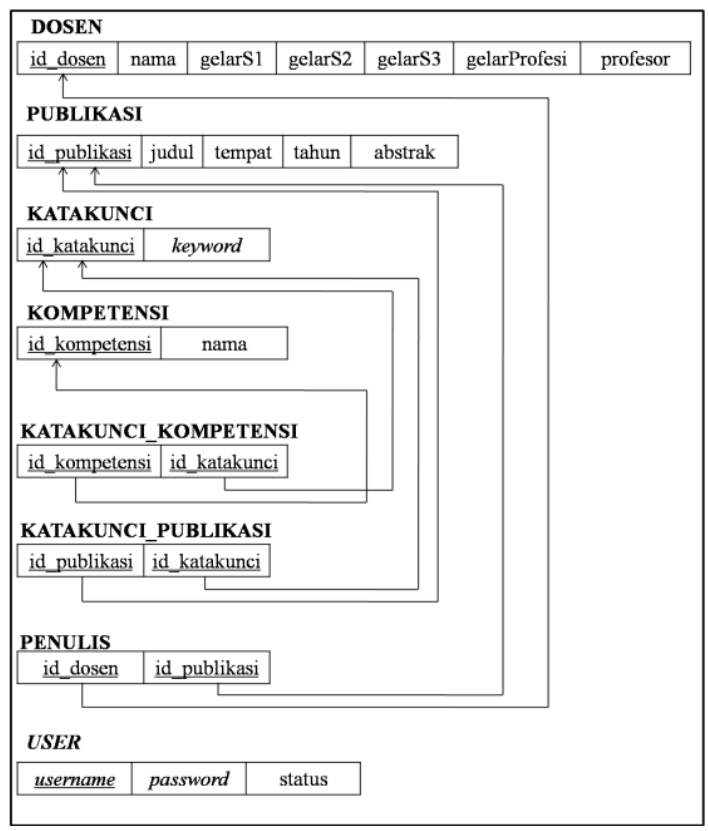

Gambar 6. Pemetaan Basis Data Sistem Pencari Pakar

\subsection{Penerapan Association rules}

Berdasarkan Gambar 6, kita dapat mengetahui hubungan antara suatu bidang kompensi dengan dosen-dosen yang memiliki kompetensi dalam bidang tersebut. Kompetensi tersebut tercermin dengan melalui publikasi ilmiah yang ditulis oleh dosen tersebut. Association rules pada Sistem Pencari Pakar ini adalah $x \rightarrow y$ dengan $x$ adalah bidang kompetensi dan $y$ adalah nama dosen.

Dalam Sistem Pencari Pakar ini, tiap bidang kompetensi memiliki kata kunci. Tiap bidang kompetensi tersebut dapat memiliki lebih dari satu kata kunci. Kata kunci tiap kompetensi itulah yang akan dicocokkan dengan judul serta abstrak dari publikasi ilmiah. Dengan demikian, kita dapat mengetahui publikasi ilmiah yang membahas suatu bidang kompetensi. Dari situ pula, dosen-dosen yang telah menulis publikasi tentang suatu bidang kompetensi diketahui.

Untuk mengetahui publikasi ilmiah beserta penulisnya yang membahas suatu bidang kompetensi, penulis menjalankan query berikut ini.

\section{SELECT}

kompetensi.nama as kompetensi, publikasi.id_publikasi ,

publikasi.judul, dosen.nama as dosen,

dosen.gelarS1 as S1, dosen.gelarProfesi as profesi,

dosen.gelarS2 as S2, dosen.gelarS3 as S3,

dosen.profesor as profesor

FROM

publikasi, katakunci, kompetensi,

katakunci_publikasi ,

katakunci_kompetensi, dosen, penul is

WHERE

publ ikasi .id_publ ikas i=kat akunci_publ ikasi . id_publ ikasi AND

katakunci_publikasi .id_katakunci=katakunci .id_kata kunci AND

kat akunci .id_kat akunci=kat akunci_kompetens i . id_kat akunci AND

kat akunci_kompetens i .id_kompetens i $=$ kompetens i .id_k ompetensi AND

publikasi.id_publikasi=penul is.id_publikasi AND

penul is.id_dosen=dosen.id_dosen

GROUP BY

dosen.id_dosen, publikasi.judul, kompetensi.nama

ORDER BY

id_publikasi, dosen.nama

Dari query tersebut, rules yang digunakan sebagai masukan pada metode association rules adalah yang terdapat pada kolom kompetensi dan dosen di tiap barisnya. Dengan demikian, rules yang terbentuk adalah \{kompetensi, dosen\}.

\subsection{Alur Sistem}

Berdasarkan analisis yang dilakukan penulis, sistem ini memiliki kebutuhan data sebagai berikut:

- Data dosen yang meliputi nama dan gelar. Hal ini diperlukan untuk menjawab pertanyaan pengguna sistem ini, yaitu siapakah yang merupakan ahli di suatu bidang. Gelar dibutuhkan untuk menjadi pembanding suatu dosen dengan dosen lain jika publikasi yang 
telah dibuat berjumlah sama banyak. Dosen yang memiliki strata pendidikan lebih tinggi dibandingkan dosen lain yang memiliki publikasi dalam jumlah yang sama akan terpilih menjadi pakar menurut sistem ini. Di sini, nama dosen diganti dengan indeks huruf dari A sampai BG yang berjumlah sebanyak 59.

- Data publikasi yang akan digunakan untuk menentukan kepakaran dosen Fasilkom UI. Data publikasi tersebut meliputi judul, tempat publikasi, tahun publikasi, abstrak, serta penulis. Dengan memasukkan data publikasi ke Sistem Pencari Pakar ini, format data yang akan diolah akan sama, yaitu dalam format string pada basis data. Hal ini akan mempermudah dalam proses pengolahan data untuk mencari pakar. Proses pencarian tersebut dilakukan dengan menjalankan query pada basis data.

- Data bidang kompetensi serta beberapa kata kunci yang bersesuaian dengan bidang kompetensi tersebut. Untuk penelitian ini, penulis menggunakan delapan belas kompetensi di bidang ilmu komputer dan sistem informasi. Kata kunci tersebut dibuat berdasarkan pada beberapa kata spesifik pada suatu bidang kompetensi yang diambil dari yang muncul pada publikasi ilmiah.

- Setelah memasukkan kompetensi dan kata kunci, admin sistem harus melakukan pencarian kata kunci pada publikasi ilmiah. Sistem akan menjalankan kode berikut ini untuk mencari dan mencocokkan kata kunci pada publikasi dengan daftar kata kunci.

\$query_truncate="TRUNCATE

‘katakunci_publikasi`";

mysq1_query(\$query_truncate);

\$query_keyword $=$ "SELECT $*$ FROM katakunci"; \$result_keyword=mysql_query (\$query_keyword); \$row_keyword=mysql_num_rows (\$result_keyword);

\$query_katakunciPubl ikasi=" INSERT

katakunci_publikasi (id_publikasi,id_katakunci) VALUES ":

\section{\$length=strlen(\$query_katakunciPublikasi $)$;}

for $(\$$ counter_keyword $=0$; $\$$ counter_keyword $<\$$ row_ke yword; \$counter_keyword++)\{

\$query_publikasi="SELECT id_publikas i

FROM publikasi WHERE lcase(judul) LIKE

'\%".mysql_result (\$result_keyword, \$counter_keywo

rd, 'keyword')."\%' OR lcase(abstrak) LIKE

'\%". mysq1_result (\$result_keyword, \$counter_keywo

rd, 'keyword' ). "\%'" ; \$result_publikasi=mysql_query( $\$$ query_publikasi)

; $\quad$ \$row_publikasi=mysql_num_rows $($ \$result_pub likasi);

for $(\$$ counter_publikasi $=0 ; \$$ counter_publika si<\$row_publikasi; \$counter_publikasi ++$)\{$

\$length)

if(strlen(\$query_katakunciPublikasi) >

\$query_katakunciPublikasi .=" , " ; \}

\$query_katakunciPublikasi = "(".mysql_result (\$result_publikasi , \$counter_pub likasi, 'id_publikasi')."," .mysql_result (\$result _keyword, \$counter_keyword, 'id_katakunci ' )." )" ; \}

\}

mysq1_query(\$query_katakunciPublikasi );

Untuk melakukan pencarian pakar, pengguna dapat memilih kompetensi yang tersedia di halaman utama. Setelah pengguna memilih, sistem akan memberikan hasil berupa urutan nama pakar berdasarkan nilai support dan confidence yang dicari dengan menggunakan data publikasi ilmiah yang digunakan. Hasil pencarian pakar akan ditampilkan setelah sistem menjalankan query berikut ini.

\section{SELECT DISTINCT}

kompetensi.nama as bidang, dosen.id_dosen,

dosen.nama as namadosen, dosen.gelarProfesi, dosen.gelarS1, dosen.gelarS2, dosen.gelarS3, dosen.profesor,

count(DISTINCT(publikasi.id_publikasi)) as banyak, count(DISTINCT(publikasi .id_publikasi))

/

(

SELECT

count $(*)$ as count

FROM

publikasi, katakunci, kompetensi, katakunci_publikasi,

katakunci_kompetensi, dosen, penul is

WHERE

publ ikasi.id_publikasi=kat akunci_publ ikas i.id_publikasi AND katakunci_publikasi id_kat akunci=kat akunc i.id_katakunci AND katakunci id_katakunci=katakunci_kompeten si.id_katakunci AND katakunci_kompet ens i . id_kompetens i=kompet ensi.id_kompetensi AND publ ikasi.id_publikasi=penul is.id_publ ika si AND penul is . id_dosen=dosen. id_dosen 


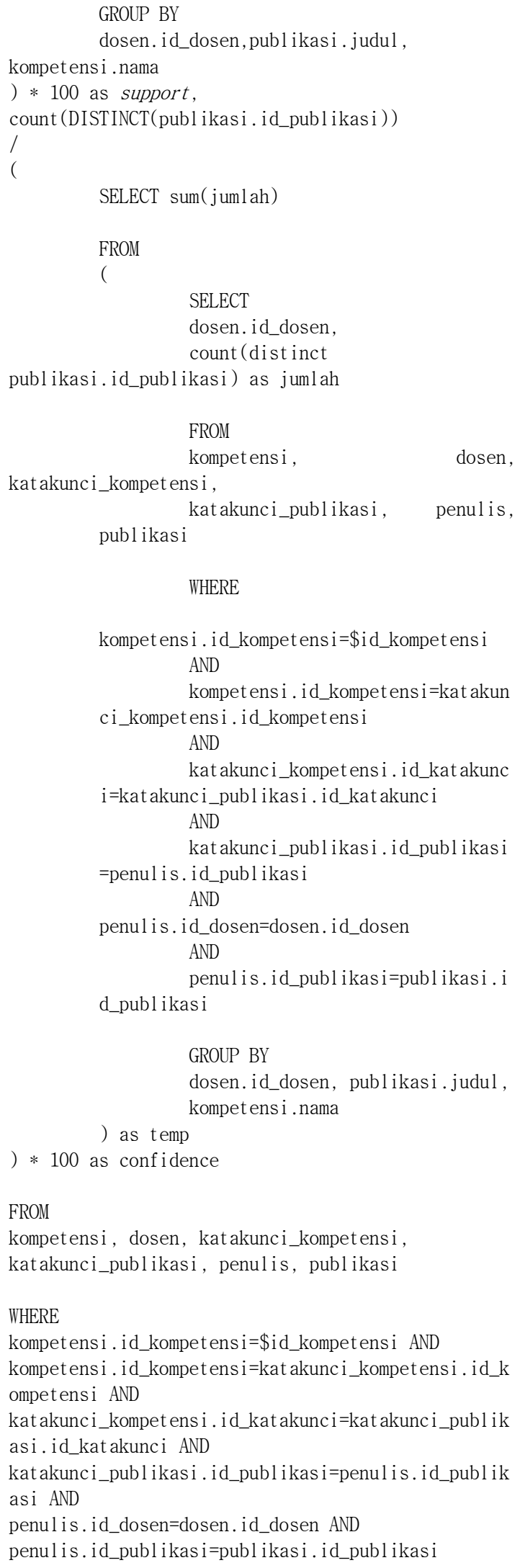

GROUP BY

bidang, namadosen

ORDER BY

bidang ASC, banyak DESC, dosen.profesor DESC, dosen.gelarS3 DESC, dosen.gelarS2 ASC, dosen.gelarProfesi DESC, dosen.gelarS1 DESC

Variabel \$id_kompetensi pada query tersebut merupakan ID dari kompetensi yang dipilih pengguna untuk dicari pakar pada kompetensi tersebut. Berdasarkan query tersebut, pakar di suatu bidang didapatkan dengan mengambil baris pertama.

Nilai support didapatkan dari banyaknya kemunculan secara bersamaan bidang kompetensi dengan nama dosen dengan banyaknya data. Kemudian format hasil pembagian tersebut dijadikan dalam persen dengan cara mengalikan dengan seratus. Nilai confidence didapatkan dengan melakukan pembagian nilai kemunculan secara bersamaan nama dosen dan kompetensi dengan banyaknya kemunculan kompetensi pada data tersebut.

\section{Uji Coba dan Hasil}

Berikut ini adalah hasil uji coba yang dilakukan.

TABEL II

HASIL PERCOBAAN UNTUK BIDANG KOMPETENSI ALGORITHM

\begin{tabular}{lrr}
\multicolumn{3}{c}{ ANALYSIS } \\
\hline \multicolumn{1}{c}{ Dosen } & Support \% & Confidence \% \\
\hline AZ, Drs., M.Sc., Ph.D., & 0,53 & 25,00 \\
Prof. & & \\
AD, S.Kom., Dr. & 0,53 & 25,00 \\
W, S.Kom., M.Kom. & 0,53 & 25,00 \\
AR, Drs., M.Sc. & 0,53 & 25,00 \\
\hline
\end{tabular}

TABEL III

Hasil PercobaAn untuk BidANG KomPetensi COMPUTER ARCHITECTURE

\begin{tabular}{|c|c|c|}
\hline Dosen & Support \% & Confidence \% \\
\hline BD, Ir., M.Kom., Dr.Eng. & 1,06 & 33,33 \\
\hline AP, Ir., M.Sc., Dr. & 1,06 & 33,33 \\
\hline D, Ir., M.Kom. & 0,53 & 16,67 \\
\hline E, S.Kom., M.Sc. & 0,53 & 16,67 \\
\hline
\end{tabular}

TABEL IV

Hasil PeRcobaAn UnTUK BIDANG KomPETENSI DATABASE

\begin{tabular}{lrr}
\multicolumn{1}{c}{ Dosen } & Support \% & Confidence \% \\
\hline C, S.Kom., Dr. & 1,07 & 18,18 \\
AC, Drs., M.Sc., Ph.D., Prof. & 0,53 & 9,09 \\
O, Dra., M.Sc., Ph.D., Prof. & 0,53 & 9,09 \\
H, Ir., M.Sc., Dr., Prof. & 0,53 & 9,09 \\
$\begin{array}{l}\text { U, Ir., M.L.I.S., Ph.D. } \\
\text { AN, S.Kom., M.Eng., }\end{array}$ & 0,53 & 9,09 \\
Dr.Eng. & 0,53 & 9,09 \\
AD, S.Kom., Dr. & & \\
AP, Ir., M.Sc., Dr. & 0,53 & 9,09 \\
AE, dr. & 0,53 & 9,09 \\
AQ, S.Kom., M.Sc. & 0,53 & 9,09 \\
& 0,53 & 9,09 \\
\hline
\end{tabular}


TABEL V

HASIL PERCoBAAN UNTUK BIDANG KOMPETENSI $E$ -

COMMERCE

\begin{tabular}{|c|c|c|}
\hline Dosen & Support \% & Confidence \% \\
\hline AQ, S.Kom., M.Sc. & 1,60 & 50,00 \\
\hline U, Ir., M.L.I.S., Ph.D. & 0,53 & 16,67 \\
\hline T, S.Kom., M.Kom. & 0,53 & 16,67 \\
\hline AO, B.B.A., M.Sc. & 0,53 & 16,67 \\
\hline
\end{tabular}

TABEL VI

HASIL PERCOBAAN UNTUK BIDANG KOMPETENSI E-LEARNING

\begin{tabular}{lrr}
\hline \multicolumn{1}{c}{ Dosen } & Support \% & Confidence \% \\
\hline B, S.Kom., M.Kom., Dr. & 1,07 & 33,33 \\
AW, S.Kom., M.Kom. & 1,07 & 33,33 \\
E, S.Kom., M.Sc. & 1,07 & 33,33 \\
\hline
\end{tabular}

TABEL VII

HASIL PERCOBAAN UNTUK BIDANG KOMPETENSI FUZZY

\begin{tabular}{|c|c|c|}
\hline Dosen & Support \% & Confidence \% \\
\hline BD, Ir., M.Kom., Dr.Eng. & 1,07 & 50,00 \\
\hline O, Dra., M.Sc., Ph.D., Prof. & 0,53 & 25,00 \\
\hline $\begin{array}{l}\text { AN, S.Kom., M.Eng., } \\
\text { Dr.Eng. }\end{array}$ & 0,53 & 25,00 \\
\hline
\end{tabular}

TABEL VIII

HASIL PERCOBAAN UNTUK BIDANG KOMPETENSI GRAPHIC

\begin{tabular}{lrr}
\hline \multicolumn{1}{c}{ Dosen } & Support \% & Confidence \% \\
\hline H, Ir., M.Sc., Dr., Prof. & 2,14 & 28,57 \\
AD, S.Kom., Dr. & 2,14 & 28,57 \\
AN, S.Kom., $\quad$ M.Eng., & 1,60 & 21,43 \\
$\begin{array}{l}\text { Dr.Eng. } \\
\text { C, S.Kom., Dr. }\end{array}$ & 1,07 & \\
U, Ir., M.L.I.S., Ph.D. & 0,53 & 14,29 \\
\hline
\end{tabular}

TABEL IX

Hasil PERCoBAAN UNTUK BIDANG KOMPETENSI INFORMATION RETRIEVAL

\begin{tabular}{|c|c|c|}
\hline Dosen & Support \% & Confidence \% \\
\hline AM, Dra., Ph.D. & 2,14 & 17,39 \\
\hline AD, S.Kom., Dr. & 2,14 & 17,39 \\
\hline H, Ir., M.Sc., Dr., Prof. & 1,60 & 13,04 \\
\hline U, Ir., M.L.I.S., Ph.D. & 1,60 & 13,04 \\
\hline $\begin{array}{l}\text { AN, S.Kom., M.Eng., } \\
\text { Dr.Eng. }\end{array}$ & 1,07 & 8,70 \\
\hline BD, Ir., M.Kom., Dr.Eng. & 0,53 & 4,35 \\
\hline C, S.Kom., Dr. & 0,53 & 4,35 \\
\hline B, S.Kom., M.Kom., Dr. & 0,53 & 4,35 \\
\hline I, S.Kom., M.C.S. & 0,53 & 4,35 \\
\hline AT, S.Kom., M.Kom. & 0,53 & 4,35 \\
\hline Z, S.Kom., M.Kom. & 0,53 & 4,35 \\
\hline AQ, S.Kom., M.Sc. & 0,53 & 4,35 \\
\hline
\end{tabular}

TABEL $X$

HASIL PERCOBAAN UNTUK BIDANG KOMPETENSI IT GOVERNANCE

\begin{tabular}{lrr}
\multicolumn{3}{c}{ GoVERNANCE } \\
\hline Dosen & Support \% & Confidence \% \\
\hline S, Ph.D. & 2,67 & 45,45 \\
U, Ir., M.L.I.S., Ph.D. & 1,07 & 18,18 \\
AC, Drs., M.Sc., Ph.D., Prof. & 0,53 & 9,09 \\
H, Ir., M.Sc., Dr., Prof. & 0,53 & 9,09 \\
BF, S.Kom., M.Kom., Ph.D. & 0,53 & 9,09 \\
C, S.Kom., Dr. & 0,53 & 9,09 \\
\hline
\end{tabular}

TABEL XI

HASIL PERCOBAAN UNTUK BIDANG KOMPETENSI MATHEMATICS

\begin{tabular}{lrr}
\multicolumn{4}{c}{ MATHEMATICS } \\
\hline \multicolumn{1}{c}{ Dosen } & Support \% & Confidence \% \\
\hline O, Dra., M.Sc., Ph.D., Prof. & 0,53 & 20,00 \\
AN, S.Kom., M.Eng., & 0,53 & 20,00 \\
Dr.Eng. & & \\
B, S.Kom., M.Kom., Dr. & 0,53 & 20,00 \\
Z, S.Kom., M.Kom. & 0,53 & 20,00 \\
AT, S.Kom., M.Kom. & 0,53 & 20,00 \\
\hline
\end{tabular}

TABEL XII

HASIL PERCOBAAN UNTUK BIDANG KOMPETENSI NETWORK

\begin{tabular}{lrr}
\hline \multicolumn{1}{c}{ Dosen } & Support \% & Confidence \% \\
\hline BG, Ir., M.L.S., Ph.D. & 1,07 & 25,00 \\
B, S.Kom., M.Kom., Dr. & 1,07 & 25,00 \\
Z, S.Kom., M.Kom. & 0,53 & 12,50 \\
AA, S.Kom., M.Kom. & 0,53 & 12,50 \\
AT, S.Kom., M.Kom. & 0,53 & 12,50 \\
F, S.T., M.Si. & 0,53 & 12,50 \\
\hline
\end{tabular}

TABEL XIII

HASIL PERCOBAAN UNTUK BIDANG KOMPETENSI NEURAL

NETWORK

\begin{tabular}{lrr}
\multicolumn{4}{c}{ DETWORK } & Support $\%$ & Confidence $\%$ \\
\hline AC, Drs., M.Sc., Ph.D., Prof. & 1,07 & 22,22 \\
BD, Ir., M.Kom., Dr.Eng. & 1,07 & 22,22 \\
AB, S.Kom., M.Kom. & 1,07 & 22,22 \\
H, Ir., M.Sc., Dr., Prof. & 0,53 & 11,11 \\
AN, S.Kom., M.Eng., & 0,53 & 11,11 \\
$\begin{array}{l}\text { Dr.Eng. } \\
\text { I, S.Kom., M.C.S. }\end{array}$ & 0,53 & \\
\hline
\end{tabular}

TABEL XIV

HASIL PERCOBAAN UNTUK BIDANG KOMPETENSI OPEN

SOURCE

\begin{tabular}{lrr}
\multicolumn{3}{c}{ SOURCE } \\
\hline \multicolumn{1}{c}{ Dosen } & Support \% & Confidence \% \\
AG, S.Kom., M.Kom., Dr. & 0,53 & 50,00 \\
AP, Ir., M.Sc., Dr. & 0,53 & 50,00 \\
\hline
\end{tabular}

TABEL XV

HASIL PERCOBAAN UNTUK BIDANG KOMPETENSI

PROGRAMMING

\begin{tabular}{rrr}
\multicolumn{3}{c}{ PROGRAMMING } \\
\hline Dosen & Support \% & Confidence \% \\
\hline AP, Ir., M.Sc., Dr. & 1,60 & 75,00 \\
I, S.Kom., M.C.S. & 0,53 & 25,00 \\
\hline
\end{tabular}

TABEL XVI

HASIL PERCOBAAN UNTUK BIDANG KOMPETENSI ROBOTIC

\begin{tabular}{lrr}
\hline \multicolumn{1}{c}{ Dosen } & Support \% & Confidence \% \\
\hline BD, Ir., M.Kom., Dr.Eng. & 5,35 & 71,43 \\
E, S.Kom., M.Sc. & 2,14 & 28,57 \\
\hline
\end{tabular}

TABEL XVII

HASIL PERCOBAAN UNTUK BIDANG KOMPETENSI SECURITY

\begin{tabular}{lrr}
\hline \multicolumn{1}{c}{ Dosen } & Support \% & Confidence \% \\
\hline I, S.Kom., M.C.S. & 1,07 & 50,00 \\
AL, Drs., M.Math., Ph.D. & 0,53 & 25,00 \\
F, S.T., M.Si. & 0,53 & 25,00 \\
\hline
\end{tabular}


TABEL XVIII

HASIL PERCOBAAN UNTUK BIDANG KoMPETENSI SEMANTIC

\begin{tabular}{lrr}
\hline \multicolumn{1}{c}{ Dosen } & Support \% & Confidence \% \\
\hline B, S.Kom., M.Kom., Dr. & 1,07 & 28,57 \\
AW, S.Kom., M.Kom. & 1,07 & 28,57 \\
E, S.Kom., M.Sc. & 1,07 & 28,57 \\
AQ, S.Kom., M.Sc. & 0,53 & 14,29 \\
\hline
\end{tabular}

TABEL XIX

HASIL PERCOBAAN UNTUK BIDANG KOMPETENSI SOFTWARE ENGINEERING

\begin{tabular}{rrr}
\multicolumn{3}{c}{ ENGINEERING } \\
\hline Dosen & Support \% & Confidence \% \\
\hline Y, Ir., M.Sc., Dr. & 0,53 & 50,00 \\
AP, Ir., M.Sc., Dr. & 0,53 & 50,00 \\
\hline
\end{tabular}

\section{Verifikasi}

Setelah melakukan percobaan, penulis melakukan verifikasi terhadap hasil yang diperoleh. Verifikasi tersebut dilakukan dengan mencocokkan bidang kompetensi yang tercantum pada biodata dosen yang berada di urutan pertama tiap bidang kompetensi. Kecocokan antara hasil percobaan dengan yang sebenarnya diperoleh bila bidang kompetensi yang dimiliki oleh dosen tersebut sama dengan bidang kompetensi yang diprediksi oleh sistem. Data yang digunakan untuk mencocokkan hasil pencarian pakar tersebut berasal dari biodata dosen yang terdapat di website Fasilkom UI serta Sistem Informasi Kepakaran Universitas Indonesia (http://sikap.ui.ac.id). Hal yang dilihat pada biodata dosen adalah bidang minat (interest), laboratorium penelitian, atau bidang yang diambil ketika menjalani pendidikan S3.

TABEL XX

VERIFIKASI HASIL PERCOBAAN

\begin{tabular}{clrlll}
\multicolumn{7}{c}{ VERIFIKASI HASIL PERCOBAAN } \\
$\begin{array}{llllll}\text { Percobaa } \\
\mathrm{n}\end{array}$ & $\begin{array}{l}\text { Sesua } \\
\mathrm{i}\end{array}$ & $\begin{array}{l}\text { Percobaa } \\
\mathrm{n}\end{array}$ & $\begin{array}{l}\text { Sesua } \\
\mathrm{i}\end{array}$ & $\begin{array}{l}\text { Percobaa } \\
\mathrm{n}\end{array}$ & $\begin{array}{l}\text { Sesua } \\
\mathrm{i}\end{array}$ \\
\hline 1. & Ya & 7. & Ya & 13. & Tidak \\
2. & Ya & 8. & Ya & 14. & Tidak \\
3. & Ya & 9. & Ya & 15. & Ya \\
4. & Ya & 10. & Ya & 16. & Tidak \\
5. & Tidak & 11. & Tidak & 17. & Tidak \\
6. & Ya & 12. & Ya & 18. & Ya \\
\hline
\end{tabular}

Berdasarkan tabel di atas, banyaknya bidang kompetensi yang mendapatkan pakar yang sesuai adalah sebanyak 12 bidang dari 18 bidang. Dengan demikian, persentase keefektifan model penggunaan association rules dalam pencarian pakar yang dikembangkan pada penelitian ini dapat dihitung sebagai berikut.

$$
\begin{aligned}
& \begin{array}{l}
\text { tingkat keefektifan } \\
\text { banyaknya prediksi yang sesuai }
\end{array} \\
& \begin{array}{l}
\text { banyak prediksi } \\
\text { tingkat keefektivan }=\frac{12}{18} \times 100 \% \\
\text { tingkat keefektivan }=66,67 \%
\end{array}
\end{aligned}
$$

\section{Kesimpulan}

Berdasarkan penelitian yang telah penulis lakukan didapatkan kesimpulan sebagai berikut.

1. Association rules dapat digunakan untuk mencari kepakaran di suatu bidang berdasarkan pada publikasi ilmiah yang telah dibuat. Hal ini karena dengan association rules, kita dapat melihat asosiasi antara suatu bidang kompetensi dengan penulis publikasi ilmiah. Semakin tinggi asosiasinya, dalam hal ini nilai support, dapat dikatakan semakin tinggi pula kepakaran penulis publikasi ilmiah tersebut pada bidang itu dibandingkan dengan yang lainnya.

2. Pencarian pakar dengan association rules ini dapat dilakukan dengan cara menentukan hal yang dibahas pada suatu publikasi ilmiah berdasarkan kata kunci yang telah ditentukan.

3. Pencarian pakar dengan menggunakan publikasi ilmiah sangat bergantung pada sampel yang digunakan. Ketika publikasi yang digunakan sebagai sampel lebih banyak yang tidak mencerminkan kompetensi utama yang dimiliki, hasil yang didapatkan akan jauh dari kondisi sebenarnya.

4. Pemilihan kata kunci untuk setiap bidang kompetensi sangat mempengaruhi hasil pencarian pakar karena dengan kata kunci tersebut itulah suatu publikasi ilmiah akan digolongkan sebagai publikasi ilmiah dari suatu bidang kompetensi.

5. Bila ada minimal dua orang yang memiliki banyak publikasi yang sama pada suatu bidang, orang yang diambil sebagai pakar adalah hanya dengan memperhatikan strata pendidikannya. Orang yang memiliki strata pendidikan lebih tinggi akan dipilih sebagai pakar.

6. Kesimpulan poin 5 dapat menjadi kelemahan pada penelitian ini karena tidak memperhatikan latar belakang jenis pendidikan. Sebagai contoh adalah orang yang memiliki gelar doktoral di bidang ekonomi akan dinilai sama dengan orang yang memiliki gelar doktoral di bidang ilmu komputer.

\section{Saran}

Setelah melakukan penelitian ini, penulis memberikan saran sebagai berikut ini.

1. Data publikasi banyak tersedia di Internet dalam berbagai keadaan, seperti file PDF, Word, hasil scan dan sebagainya. Sebaiknya untuk penelitian selanjutnya, gunakan teknikteknik khusus untuk melakukan pengolahan data dalam bentuk file tersebut tanpa harus menyamakan format secara manual. 
2. Data publikasi yang digunakan sebaiknya lebih banyak lagi karena untuk mendapatkan hasil yang lebih akurat dan tidak banyak penulis yang mendapatkan nilai confidence yang sama pada suatu bidang.

3. Kata kunci yang digunakan sebaiknya berjumlah kurang lebih sama untuk tiap bidang dan lebih spesifik merujuk pada bidang kompetensi tertentu sehingga publikasi ilmiah yang ada dapat digolongkan sebagai publikasi ilmiah dari suatu bidang kompetensi dengan jelas.

4. Penggunaan bobot untuk membedakan nilai yang diterima antara penulis pertama, kedua, ketiga, dan seterusnya pada publikasi ilmiah.

5. Penggunaan nilai minimum support serta minimum confidence sebagai nilai potong untuk support serta confidence untuk mengkategorikan pakar atau bukan pakar.

Mencari metode lain yang lebih efektif dari pada yang telah penulis lakukan pada penelitian ini.

\section{Referensi}

[1] Elmasri, R., \& Navathe, S. B. (2007). Fundamentls of Database Systems (5 th. ed.). New Jersey: Pearson Prentice Hall.

[2] Fernandez, I. B., Gonzales, A., \& Sabherwal, R. (2004). Knowledge management Challenges, Solutions, and Technologies. New Jersey: Pearson Prenctice Hall.

[3] Robbins, S. P., \& Coulter, M. (2005). Management (8th ed.). New Jersey: Pearson Prentice Hall.

[4] Stoner, J. A. (2006, Mei 2). Pengertian / Definisi dari Manajemen. Dipetik Februari 12, 2010, dari Organisasi.org: http://organisasi.org/pengertian_definisi_dari _manajemen

[5] Hendrik. (2003). Sekilas Tentang Knowledge management. Ilmu Komputer.

[6] Setiarso, B. (2006). Manajemen Pengetahuan (Knowledge management) dan Proses Penciptaan Pengetahuan. Ilmu Komputer.

[7] Pusat Bahasa, D. P. (2008). Daftar Kata: pakar. Dipetik Juni 20, 2010, dari Kamus Besar Bahasa Indonesia (KBBI Daring): http://pusatbahasa.diknas.go.id/kbbi/index.ph $\mathrm{p}$

[8] Ensiklopedia Reference.com. (2008). Dipetik
Juni 20, 2010, dari Reference.com: http://www.reference.com/browse/expert

[9] Rahmat. (2008, Agustus 8). Konsep Dasar Sistem Pakar. Dipetik Juni 20, 2010, dari Rahmat Blog: http://blog.re.or.id/konsepdasar-sistem-pakar.htm

[10] Harahap, E. (2010, April 29). Pakar dan Sistem Pakar. Dipetik Juni 20, 2010, dari Perpustakaan Institut Teknologi Telkom: http://www.ittelkom.ac.id/library/index.php?o ption=com_content $\&$ view $=$ article $\&$ id $=666$ :pa kar-dan-sistempakar\&catid=6:internet $\&$ Itemid $=15$

[11] Setiarso, B. (2007). Penerapan Knowledge management pada Organisasi: Studi Kasus di Salah Satu Unit Organisasi LIPI. Ilmu Komputer.

[12] Pramudiono, I. (2003). Pengantar Data Mining. Dipetik Juni 25, 2010, dari IlmuKomputer.com:

http://ilmukomputer.org/2008/11/25/penganta r-data-mining/

[13] Liu Xinying \& Wang Peizhi. (2008). Data Mining Technology and Its Application In Electronics Commerce. IEEE .

[14] StatSoft, I. (2010). Association rules. Dipetik Juni 24, 2010, dari Electronic Statistics Textbook:

http://www.statsoft.com/textbook/association rules/\#Graphical\%20Representation\%20of\% 20Associations

[15] IBM. (2009). Confidence in an Association Rule. Dipetik Juni 2010, 23, dari IBM: http://publib.boulder.ibm.com/infocenter/db2l uw/v8/index.jsp?topic=/com.ibm.im.model.d oc/c_confidence_in_an_association_rule.html

[16] IBM. (2009). Support in an association rule. Dipetik Juni 23, 2010, dari IBM:

http://publib.boulder.ibm.com/infocenter/db21 uw/v8/index.jsp?topic=/com.ibm.im.model.d oc/c_support_in_an_association_rule.html

[17] Fernandez, I. B. (2000). Facilitating the Online Search of Experts at NASA using Expert seeker People-Finder. Proceeding of the Third International Conference on Practical Aspects of Knowledge management.

[18]Fernandez, I. B. (2001). Searching for Experts with Expertise-Locator Knowledge management Systems. 